\title{
Fear of a Nonwhite Planet: Clare Boothe Luce, Race, and American Foreign Policy
}

MARCO MARIANO

$\mathrm{C}$

Ilare Boothe Luce was arguably one of the most well-known and controversial women in midcentury America. Journalist and playwright, Connecticut Republican congresswoman and New York socialite, she was also the first American woman to be assigned to a major diplomatic post, as she was the U.S. ambassador to Italy from 1953 to 1956.

In the first part of this essay, I discuss her racialized view of international affairs as it took shape in the aftermath of Pearl Harbor. At a time when the United States had been attacked by a nonwhite power, Luce was among those Americans who came to envision America's place in the world and its pursuit of national security in the light of what she saw as the worldwide, deadly struggle between whites and nonwhites that was unleashed by World War II.

In the second part, I deal with her support for limited quotas of immigrants from Asia and the African Americans' quest for desegregation and civil rights during and after the war as evidence that she had embraced the new perspective on international affairs and race that came of age in the United States in the 1940s as a consequence of both the impact of Nazi atrocities and the ideological competition posed by communist internationalism.

Finally, I argue that some aspects of Luce's policies as the U.S. ambassador in Italy, as well as some of her views of Italian politics and society, suggest that old assumptions regarding the relation between race, ethnicity, and democracy retained some influence on her foreign-policy outlook at a time when these assumptions were banned by mainstream rethoric and were losing their grip on the American diplomatic mind.

$$
* \quad * \quad *
$$


World War II was a turning point for Americans' attitudes about race at home and abroad. Waged by a multiracal but segregated army against Nazi racial hatred, it hardly brought about the "double victory" advocated by African American activists. However, it set the stage for the wave of mobilization of the 1950s and 1960s: black Americans who had fought in Europe, North Africa, and the Pacific were much less willing to accept segregation and discrimination upon their return home.

Black and white Americans were by no means the only groups involved in wartime racial tensions, which reached their peak with the internment of Japanese Americans. On the one hand, the war in the Far Eastern/Pacific front - unlike the one against Nazi Fascism in Europe - had explicit racial undertones. Works by John Dower, Akira Iriye, and Christopher Thorne have shown how, particularly after Pearl Harbor, stereotypes about race contributed to shape the dominant view of Japan and the Japanese. ${ }^{1}$ On the other, in the aftermath of a war fought in the name of democracy against racial hatred, the rethoric and practice of white supremacy came to be challenged as never before. The consequences of Nazi racial ideology seemed to have exposed the "fallacy of race" once and for all, thus making segregation and race-based restrictions to immigration politically costly, as well as morally untenable, at a time of unprecedented U.S. involvement in world affairs. ${ }^{2}$

The emergence of the United States as a global power put its record in terms of race relations under worldwide scrutiny, especially in the nonwhite, colonized areas of the world where the color-blind Marxist internationalism promoted by local Communist parties and Soviet propaganda sounded very appealing. As a consequence, desegregation at home as well as the rethinking of U.S. relations with nonwhite nations came to be a cold war imperative. In the early cold war, policymakers in Washington, D.C., were aware that America's stance on race was fundamental for their credibility in the ideological confrontation with the Soviet Union: facing the race issue at home was now relevant to the pursuit of national interest and, ultimately, to national security.

As race relations at home were again undergoing a redefintion, ideas of whiteness were in flux as well. In November 1936 the first issue of Life magazine dedicated its major foreign news piece to the coming Pan-American Conference in Buenos Aires: a photo-essay about Brazil underscored that a different idea of whiteness prevailed in the "biggest American republic." The caption of a photograph of couples of various complexions dancing in Rio de Janeiro explained that

the man with the black hat is considered practically white in Brazil. His companion in the dance at Rio's suburb of Penha is much lighter, with definitely European features. She is an accepted white woman, happily married to the "practically white" man. The youth with grey coat and white trousers has a good mixture of Indian and Portuguese blood. All these are consid- 
erably lighter than the "white men" of Northern Brazil. Rio's citizens . . . are predominantly white. But many a Rio's aristocrat has black kinsmen and in Negroid northern Brazil a drop of white blood makes a man "white."

This apparently detached portrait of racial habits had explicit political implications. The general description of Brazil in the first page of the story informed Life readers that

Brazil ... is called by scientists the most valuable of human property owned by a European race. Brazil is also called "a colossal human failure." Brazilians are charming people but are incurably lazy. The original Portuguese conquistadors did not bring their wives, married Indian aborigines and their descendants added the blood of negro slaves to the strain. The mixture did not work. Brazil once produced most of the world's sugar and rubber. It lost both these businesses by sheer laziness to more energetic races. ${ }^{4}$

The juxtaposition is telling: nations where whiteness is defined in terms that are different from American standards are doomed to failure.

Ten years later, when the United States was emerging as the leader of the Free World, a worldview inspired by such an explicit hierarchy of race would have to be expressed with more restrain. However, notions of race in general and whiteness in particular were still a cultural construction shaped by class, interest, and power, and were all the more dictated by and relevant to "national interest" as it was seen by the American foreignpolicy establishment. ${ }^{5}$

Clare Luce was by no means a core member of this establishment. However, her awareness of the dynamic relations between American foreign policy on the one hand and notions of race and ethnicity on the other is an example of the widespread changes taking place in 1940s America.

At the time of American entry in World War II, Clare was enjoying increasing success in New York circles as a journalist and playwright. In 1932, at twenty-nine, she became managing editor of Vanity Fair, and in 1936 she authored the Broadway hit The Women. Thanks to both her ambition and her marriage to the publisher Henry Luce in 1935, she found herself part of an extended network of influential public figures, which allowed her to build personal ties with, among others, former president Herbert Hoover, financier Bernard Baruch, and American Ambassador to Great Britain Joseph Kennedy. A few months after American entry into World War II, she would enter politics by running successfully for a seat in the House of Representatives as the Republican candidate of Fairfield County, Connecticut.

The outbreak of World War II strongly increased her interest in foreign 
affairs. Eager to return to journalism and determined to take advantage of her access to Henry Luce's magazines, in February 1940 she left for a three-month trip to Italy, France, Belgium, and Great Britain as a special correspondent for Life. Visiting the European front at a time when Germany's westward expansion was about to put an end to the so-called phony war and nonbelligerent Italy was finally ready to follow its lead, Clare came to believe that the European crisis posed a serious threat to America itself. An account of her trip, Europe in the Spring - an expanded version of her articles for Life published in September 1940 by Alfred A. Knopf and reprinted eight times - shows her willingness to embrace her husband's interventionist inclinations. ${ }^{6}$

The common interest in foreign affairs played an important part in the intellectual exchange between Clare and Henry Luce. Clare was everything but intimidated by Harry's success in business and influence in politics, and her witty, outspoken cynicism was frequently at odds with his deep-rooted religious moralism. However, foreign affairs provided a common ground on which the two could relate, even in the midst of private tensions. Arguably the most influential among the unofficial architects of American foreign policy in the war years, since the late 1930s Henry Luce had urged President Roosevelt to assume a more active role in the international crisis. In late April 1941 he had joined Clare in Europe, and in mid-May the two hastily left Brussels for Paris as German troops had already entered Belgium. Once back in New York City he became a member of the Century Group, a small organization that - together with William Allen White's Committee to Defend America by Aiding the Allies - turned out to be among the most effective in the interventionist camp as a pressure group on the White House. He became one of the leaders of the Century Group because more than any other of its members he was in a position to influence American public opinion; in fact he did not hesitate to enlist Time, Life, and Fortune in his anti-isolationist crusade.

The group was composed of a limited number of public leaders, businessmen, journalists, and intellectuals who embodied the characteristics of the Northeastern elite: mostly Protestants of Anglo-Saxon origin, educated in Ivy League universities, with slightly more Democrats than Republicans but usually conservative on domestic issues, familiar with European affairs, and personally acquainted with Great Britain. While their pro-war stance was mainly due to their view of Nazi Fascist expansionism as a threat to American interests, their Anglophilism undoubtedly played a role. Their assumption that the interdependence of the two major Anglo-Saxon countries extended to the realm of security had somehow a racial tinge, which was emphasized by the cultural otherness of the NaziSoviet - let alone the Japanese - threat. ${ }^{7}$ More often than not, they articulated their vision of Anglo-American kinship in historical and cultural, as well as economic and strategic, terms. Francis Pickens Miller, coordinator of the group, had been the organizational director of the Council of Foreign Relations: During the war he would join the Office of Strategic Sevices and, later, the State Department. In a July 1941 article for For- 
eign Affairs he called for an Atlantic, as opposed to hemispheric, strategic outlook based on "material and spiritual interests." For Miller, a Rhodes scholar, "The North Atlantic Area is the cradle of our civilization ... For more than a thousand years our fathers have been building a common society around the shores of the North Atlantic. They built it by labor, by faith, and, when necessary, by arms ... The Atlantic Ocean has become the ocean of freedom."8

For all his Sinofilia and his trust in and advocacy of America's global as opposed to regional - reach, Henry Luce shared this pro-British, Atlantic outlook and was at ease among the Centurions. Henry Luce's mother was a descendant of Elihu Root, the revered mentor of the American foreign-policy establishment, and Luce had studied at Oxford after graduating from Yale. England and his empire played a crucial role in his vision of an American Century. In an essay he wrote after his return from England in March 1942 and confidentially circulated among Time Inc. editors, he reaffirmed his vision of the coming American century as follows: "A victorious America, counter-thrusting against the enemies of mankind, must inevitably seek to establish a world wide influence. In effect America will be inviting England to validate the supremacy of an international law based on Anglo-American power and ideas of justice." To this end England, although declining, was still the only indispensable ally to the U.S.: "Her supremacy is over but she may largely determine what and who comes after ... Just as it was at the beginning of England's triumphal centuries, so it is at the end - England holds the balance of power." More specifically, Henry Luce admired the British Empire as the major instrument for the expansion of "civilization," and blamed the "Englishmen" for not being proud of its achievements: "In particular they are not proud of India as they ought to be ... If there has been dishonor in India, so also there has been honor - great honor, none greater in the dealings of one trimphant civilization with a civilization decayed and rotten." Not surprisingly Luce especially valued the Empire as the major outpost of white civilization in the nonwhite world, as he critized Britain for placing too much emphasis on its "European connection" and overlooking the "whiteman's countries": Rhodesia, Australia, and Canada. ${ }^{9}$ This characteristic twist of his vision was not missed by left-wing critics like Norman Thomas and Freda Kirchwey, who attacked his American Century for echoing Manifest Destiny and the "white man's burden."10

In this respect Luce was no exception: some American advocates of intervention and sectors of the public opinion that urged the Roosevelt administration to fully support the British war effort were moved by old perceptions of the kinship between the "English-speaking peoples," as well as by the will to react against totalitarian expansion on the other side of the Atlantic. ${ }^{11}$ The support of Clare Luce, as well as several Time Incers, for the so-called Atlantic Union movement was part of this larger picture. The Atlantic Union movement was the creation of Clarence Streit, a relatively obscure journalist whose Union Now. A Proposal for a Federal Union of the Democracies of the North Atlantic (1938) called for a world federation, 
based on the blueprint of the U.S. federation, as the only alternative to the approaching storm of another world war. The book ended up selling 300,000 copies worldwide and was well received by key figures of the Anglo-American foreign-policy establishment, like Lord Lothian and Henry Stimson. Shortly thereafter Streit founded Federal Union Inc., a nationwide organization that gained open or private support from personalities ranging from Eleanor Roosevelt to John Foster Dulles. ${ }^{12}$

According to Streit, however, the immediate realistic goal was a federation among fifteen countries, including North America, Northwestern Europe and Scandinavia, and the British Dominions, based on their cultural, economic, and political homogeneity or, in Streit's words, their "natural bonds." He compared this North Atlantic world to what the Mediterranean had been at the time of the Roman Empire - a familiar analogy among Atlanticists - and emphasized that "[t]he culture of our fifteen is inextricably interconnected. Proceeding from the same basic Greek-Roman-Hebrew mixture grafted on the same dominant Teutonic-Celtic stock, the civilization of these democracies has reached broadly the same level." ${ }^{13}$ Although in the beginning he explicitly ruled a federation of the "English-speaking peoples" as it would acquire "an offensive air of exclusivity," he included Australia, New Zealand and South Africa among the "North Atlantic democracies," and in early 1941 he published Union Now with Britain, which advocated an emergency union between the United States and the British Empire.

Unlike her husband, Clare Luce took Streit's blend of Anglo-Saxon neoimperialism and Lippmann-like liberal Atlanticism quite seriously. She saw in Union Now the positive rationale for going to war - a "destiny," in her characteristically emphatic words, that is the expansion of peace and prosperity, freedom and democracy, as opposed to the sheer "defense" visà-vis Nazi aggression. She became a member of the Executive Committee of Federal Union Inc., helped Streit to raise funds, and participated in at least two Federal Union public events. In a brief speech in September 1940 she focused on the need for American support for England by encouraging "a frank awoval of our political kinship, cemented by our mutual ideals," and relied on Edmund Burke's appeal for reconciliation between England and the American colonies as the best precedent for Anglo-American solidarity. A few months later, with most of continental Europe under Nazi Fascist domination, she urged "the 7 remaining democracies, the United States, Canada, the United Kingdom, Eire, Union of Sourth Africa, Australia, and New Zealand" to form a federal union to face the common enemy. Her main target was American isolationism, and her endorsement of Streit was part of the attack against hemispherism under way since the late 1930s: "Are the spiritual frontiers of freedom to be bounded by the oceans? In the world of man's soul, there are no hemispheres and the spirit of Liberty admits of No Monroe doctrines."14

Streit's organization gained momentum in the public arena, if not in the White House and in Congress, until the German invasion of the Sovi- 
et Union and the Japanese attack on the United States transformed the place of the United States in the war and led to the emergence of a global outlook that was at odds with Federal Union's Europe-first agenda. The events in the Far East were especially important for the Luces; indeed it was Pearl Harbor that would lead Clare to embrace a heavily racializied view of World War II.

The son of a Presbyterian missionary, Harry Luce was born and spent his boyhood in China and in the 1930s and 1940s was arguably the most influential man in shaping American images of China. Combining religious and paternalistic zeal and a secular vision of national greatness, he manufactured - and sold to Time Inc. readers - a vision of China as the only Asian country intent on adopting an American-like civilization, complete with modern customs, democratic institutions, and Protestant religion, all under the enlightened leadership of Chiang Kai-shek and his charming wife, the Wellesley graduate Soong Meiling. Such a message was very well received by Americans in the interwar years, in part because it implicitly reinforced their view of their own way of life as a superior model that the good-natured but childlike Chinese were finally embracing in their quest for civilization. ${ }^{15}$ Pearl Harbor not only strengthened the appeal of this "sentimental" view of China, but made its racial assumptions more explicit. A March 1943 issue of Life described the Chinese as physically more similar to Europeans and Americans than to the Japanese; the latter, formerly portrayed as inferiors of negligible military ability, were now packaged as atavistic, militaristic supermen. ${ }^{16}$ However, it must be stressed, this was an reversal of previous American views of Far Eastern peoples. At the turn of the century, Japan had emerged as a modern power, adopting a constitutional government, developing industrial and commercial prowess, and showing martial virtues in the wars against China and Russia. Americans were at first puzzled by the emergence of a nonwhite competitor in the Far East, but many of them, moved by strategic considerations, soon began to rationalize the "exception" of Meiji Japan: at a time when Tokyo became "an Anglo-Saxon proxy in the competition for imperial power in East Asia," Alfred Thayer Mahan saw Japanese as "adoptively European," Theodore Roosevelt admired them as a "highly civilized people," and a host of missionaries, scholars, and observers characterized them as "the most un-Mongolian people in Asia."17 By "whitening" the Japanese, traditional hierarchies of race were mantained vis-à-vis events that questioned the supremacy of whiteness in the international arena. A few decades later, on the eve of World War II, American notions of whiteness were again in flux according to the requirements of - among other things - national interest.

Clare Luce's inclination to absorb elements of Harry's cultural and political outlook and integrate them into her own distinct viewpoint is particularly evident in her interest in Chinese affairs. In April 1941 the Luces traveled to China, where they met with Chiang and the Communist general Chou En-lai, and visited the Yellow River front. Like in Europe one 
year before, Clare got a firsthand demonstration of the attacks against America's friends; her Life articles indicate that the Japanese bombings of Chungking made her more aware of the relevance of the Far Eastern front and more impatient with U.S. policy toward Japanese expansionism. Once back to New York in June, she spoke at a United China Relief fundraiser radio broadcast on $\mathrm{NBC}$, in which she frequently referred to the Chinese as "our spiritual allies and our fellow Christians" and described the ruling family as "the greatest married team in the world, with the patriotic exception of President Roosevelt and his dynamic, bountiful and far-ranging lady Eleanor." Later she would report as a Life war correspondent from the Philippines, India, and Burma. Finally, her concern with Far Eastern affairs would lead her to play an active role in the rise of the so-called China lobby, first during her four years in the House of Representatives, from 1942 to 1946, and afterward as a private citizen. As tensions with the Soviet Union mounted in the immediate postwar years, Luce and her fellow lobbysts would emphasize that China was no less important than Europe for the containment of Communism. ${ }^{18}$

On their way to China during spring 1941, the Luces stopped in the Philippines, where they met top American military officials. Clare was particularly impressed by Colonel Charles Willoughby, head of military intelligence, who was known in military circles for his right-wing inclinations and his admiration for General Douglas MacArthur. Back to Manila in October 1941 for a Life story on MacArthur, she perceived the growing fears of a Japanese attack on the Philippines; MacArthur himself expressed doubts about the possibile defense of the islands. Her interest in geopolitical and military issues was ignited when, thanks to Willoughby, she heard for the first time of Homer Lea, a geopolitical expert and military writer who in The Valor of Ignorance (1909) had predicted the ascent of Japan as a world power posing a threat to a purportedly complacent and decadent America. Clare came to embrace Lea's outlook, as well as its strongly racialized assumptions - a blunt, unrestrained version of turnof-the century social Darwinism and Anglo-Saxonism. ${ }^{19}$

Lea, a Sinophile American who had served for a decade as a military advisor to Sun Yat-Sen in the last days of the Ching dynasty, upon his return to the United States was horrified to discover what he saw as the nation's vulnerability to attack. A reluctant admirer of Japanese militarism, Lea lamented the declining martial virtue of the United States, which he ascribed to its growing wealth: "Commercialism grows as militancy deteriorates, since it is in itself a form of strife, though a debased one, a combat that is without honor or heroism." According to his Darwinist perspective, such a "desease" caused a decline that would endanger the security of any nation, including the United States: "As physical vigor constitutes health in the individual, so does it among nations ... The duration of life in an individual is determined by his power to cambat desease ... So it is among nations." 20 Ideas on the hierarchy of race played a major role in his vision of international affairs: 
Belief in the potency of gold is not new; it is as old as the Jews and prevails wherever wealth constitues power in civil life.... In any nation where wealth is the source of political power, the criterion of rank and the mark of social eminence, it becomes impossible for the people not to see in it also a complete source of military strength. People that can turn patriotism into cash and their gods into profit could not believe otherwise. ${ }^{21}$

This anti-Semitic slur comes as no surprise, given Lea's belief that racial heterogeneity was a major threat to the stability of nations, let alone to the prosperity of American republican institutions. Like other Americans of Anglo-Saxon descent of the time, Lea feared the demographic effects of both U.S. expansion to areas populated by nonwhites (the Philipines and Puerto Rico) and, even more, of massive immigration from Southeastern Europe. Referring specifically to Slavs and Italians, he remarked that "American naturalization is not a racial antiseptic" and believed that these "lower elements of Europeans" posed a threefold menace to the United States. They could not be trusted as loyal and patriotic citizens because of their relationship to their country of origin; their propension for crime was "an index to [their] national character, as well as individual." And finally they endangered American democracy because they were "in no manner imbued with the true spirit of American institutions, the preservation of those primitive rights upon which the great but fragile edifice of this Republic was builded [sic]." 22

Lea's book had enjoyed a short-lived notoriety immediately after its publication, when the Hearst press found it fitting its aggressive Yellow Peril campaign. Pearl Harbor and other Japanese successes like the fall of Manila generated a climate of opinion that rescued the book from oblivion: Secretary of War Henry Stimson, among others, expressed his admiration for Lea in his diary; in the public sphere many periodicals published stories about Lea, while geopolitical thinking came to be a matter of public interest that was discussed in newspapers and large-circulation magazines, including Time, Life, and Fortune. ${ }^{23}$ Clare Luce actively contributed to such a revival; she wrote an introduction to the Harper and Brothers reissue of The Valor of Ignorance (1942) and a two-part profile of Lea that, rejected by Life, was published by its main rival, the Saturday Evening Post.

Luce's published writings about Lea focused on the accuracy of his predictions regarding the war between the United States and Japan, as well as on his adventurous life and, needless to say, his fascination with China. While not denying his belief in Anglo-Saxon superiority, she responded to his critics that "Lea was neither a Fascist nor a Totalitarian," but a militarist, a soldier, and "a patriot." ${ }^{24}$ However, the most striking evidence of the influence of Lea's writings on Luce is a thirty-two-page memorandum she wrote to her husband on New Year's day 1942. Under the emotional influence of the Japanese attack, she vented on her husband her 
fears for the present and future of America in a long rumination, "A Luce Forecast for a Luce Century," that now reads as a partly cynical, if amateurish, attempt at geopolitical realism, partly as a statement of antidemocratic white supremacy, and partly as a gloomy, racialized prediction of the cold war. She cleary reveals her debt to Lea's militarism when she blames America for confusing "greatness and wealth with power" and in criticizing American policies in the Far East where, she wrote, "we needed to think militarily, geographically, racially, instead of sentimentally, 'liberally' and commercially," 25 thus indirectly questioning Harry's China policy. In fact her quest for a strongly armed America free of "sentimental" - that is, moral - constraints and ready to fight its way through the inevitably violent conflict among nations, "the most cannibalistic of human organisms," was as much at odds with her husband's moralizing and hegemonic vision of the coming American Centuryas with the softhearted "globaloney" she would soon famously denounce.

Clare Luce also shared Lea's view of whiteness as an asset to American security at home. Indeed, this orientation was telling of the permanence, or sudden reemergence, of Anglo-Saxonism among wartime American elites and, more generally, it showed how race helped shape visions of the war. According to Thomas Borstelmann, "World War II was not racial in its origins, but in the Pacific it became for most American soldiers a racially coded conflict," and the same was true in the home front for significant sectors of the American society and of the establishment. ${ }^{26}$ "America," she wrote to Harry Luce,

will survive as a nation only if she preserves the racial, and cultural homegeniety $[s i c]$ predominantly 'Anglo-Saxon' which until 1850, anyway, made her America. This is a matter of strict barriers against further immigrations of Brown, Black and Yellow peoples, and a desperate attempt to keep out the scum and sweepings of South Europe, the Levantine East and Asiatic Russia. ${ }^{27}$

Not only did her views on race end up leading her to embrace a familiar restrictionist pattern at home, they also led her to adapt old Anglo-Saxonist perceptions of the national interest to the new geopolitical framework of World War II and to the postwar international order. She regretted that the war was weakening the

white world [. . . ] against the inevitable Asiatic Revolt, and the also inevitable Mohammedan and India Revolts that will follow this war no matters who wins [. . . . We were and are all the European contestants unaware of the fact that we are, in the final analysis destroying ourselves for the benefit of the Mongoloid Russians and Asiatics. ${ }^{28}$ 
While her apocalyptic tone is undoubtedly related to the traumatic impact of the American defeats in the early stages of the Pacific War, some of her arguments reveal deeper currents in the political culture of predominantly Anglo-Saxon American elites. Michael Hunt has identified three core elements in the ideology of the American foreign policy: a quest for national greatness closely related to the mission of the expansion of freedom abroad; a consensus on the hierarchy of race as the element regulating American attitudes toward other peoples; and a class-conscious hostility to radical social change. Both the second and the third elements, at times thinly veiled by the high-sounding and then-fashionable jargon of geopolitics, frequently resurface in Luce's "Forecast." ${ }^{29}$ Trying to envision the future world order in case of victory against the Axis powers, she repeatedly stressed the looming threat posed by Soviet Russia and China as racially Asiatic powers that would inevitably unite against the West on the grounds of racial and ideological hatred. Her quest for a "white race solidarity" among the United States and Great Britain - and, at a later stage, Germany - was directed against "China, an Asiatic country, and Russia, too, since its revolution slaughtered most of its leading whites, predominately Mongoloid and worst of all committed to the principal of miscegenation. . . . Russia, whose ideology demands breeding with men of all colours so long as they work with their hands." Neither Chinese nor Russians, she continued, believed in their racial superiority, and therefore would find "ideological" allies among the milions af nonwhites ready to fight for "freedom" from white-man "domination" around the world. ${ }^{30}$ By explicitly intertwining the categories of class and race, Luce, a notorious elitist, reiterated old restrictionist and anticommunist sentiments and, at the same time, anticipated concerns over the color-blind appeal of communist propaganda in the nonwhite world that would come of age in the early cold war.

She defined postwar whiteness in familiar Anglo-Saxonist terms. She feared Russia, which "proselytes so successfully among the scum of our population, and in Mexico, Cuba and South America. Not to say the proselytizing she will do in the Near East and in Europe itself, on anti-racial, anti-white lines after the war is over." The immigrants from Eastern and Southern Europe would most likely cause a communist revolution in the United States, until "fleeing Anglo-Saxon Europeans, who have learned a bitter, bitter lesson" would redeem America again. ${ }^{31}$

Finally, her vent ended with an indictment of democracy and of the very political tradition of American liberalism. Not only did she hold democracy responsible for the purportedly disastrous foreign policy of the previous decade because of its propensity for "greyness of compromise" and its inclination to "sentimental" alliances, but she also found democracy incompatible with the coming imperial role of the United States in world affairs. Echoing widespread isolationist inclinations, she wrote, “'[T] police the modern world' is to abandon the 'four freedoms' abroad, 
and all freedoms at home. A democracy with a great standing army, equal to all emergencies, and with a foreign policy ready to meet them, is impossible to envisage. . . . Only totalitarianism can or will insure such a design." Luce came to see democracy itself - as well as "our American way of life, our free-enterprise system" - as dispensable vis-à-vis the goal of the preservation of America as "the top-dog among the nations of the world" and the defender of "our precious heritage of Christian, Greek, and Anglo-Saxon culture."32

Only a few months later, while campaigning for a seat in Congress, Clare Luce would stand against segregation in the armed forces and would call for "racial cooperation" from the pages of Opportunity, the periodical of the National Urban League, which had been an important voice of the Harlem Renaissance, ${ }^{33}$ and in 1945 she would support the naturalization of immigrants from India that was proposed by Emanuel Celler, the congressman from New York who worked with antropologist Franz Boas against restrictions to immigration based on national quotas. Such a turnaround cannot be explained only by the fact that she was everything but a systematic thinker, as it exemplifies the transition to a new consensus on race, immigration, and their relation to American foreign policy that was set in motion by World War II. On the one hand, Washington had gone to war with a segregated army at a time when the restrictionist immigration laws of the early 1920s were still in effect. On the other, fighting Nazism and discovering Nazi concentration camps led many Americans to deal with the atrocity of racism and to turn away at least from its most terrible forms. Political expediency played a role as well: Axis propaganda during the war, and Communist propaganda afterward, exposing American discrimination against non-European immigrants and blacks, urged the United States to "correct the remaining imperfections in our exercise of democracy," 34 in the understated but nontheless revealing words of Harry Truman's civil rights message to Congress of February 1948.

In the fall of 1942 Clare Luce was elected to Congress as the Republican representative of Fairfield County, Connecticut. There she served on the Military Affairs Committee, thus improving her command of things international. She continued to lobby in favor of China and to fully support the American war effort, notwithstanding her political disagreement with and personal dislike of President Roosevelt.

Her best-known effort against restrictions to immigration is arguably her support for the repeal of the Chinese Exclusion Act. The establishment of a quota that would allow about one hundred Chinese per year to enter the United States was "hardly a threat to American labor markets, the American way of life, or even our so-called white civilization" and was fundamental if the United States did not want to be associated with "the whole Hitler doctrine of racial theology," she said at a meeting at Columbia University in July 1943. ${ }^{35}$ While her - let alone her husband's - proChina attitude clearly accounts for this specific, limited opening to nonwhite immigration, other considerations helped shape her attitude toward 
immigration. The assault on U.S. immigration laws was one of the staples of Japan's anti-American propaganda in Asia during the war and was arguably the most convincing aspect of it among peoples who otherwise generally opposed Japanese imperialism. Liberals and others were realizing that Japan, by rhetorically asking "Will white Americans give you equality?" underscored the weak point of the U.S. appeal abroad. At the end of the war, Moscow was replacing Tokyo as the foreign power whose anticolonialist message could captivate nonwhite masses in Asia and elsewhere.

In October 1945 Clare Luce took the floor of the House of Representatives to support H.R. 3517, a bill originally introduced by Celler and herself that would authorize the naturalization of a quota of "Eastern Hemisphere Indians of India." India's quest for independence from Britain made her a crucial battleground for Anglo-Americans at a time when "the West" was about to engage in the ideological confrontation against the international communist movement. She relied on Owen Lattimore to point out that "[t]here is going to be a great deal of shopping around . . . among the Asian peoples, particularly colonial peoples for political ideologies." The ability of the United States to compete in Asia was hampered, she continued, not only by restrictions to immigration, but also by racial discrimination at home: "It is axiomatic, as any American Negro knows, that where racial discrimination exists against an individual, a group, or a nation, political and economic advancement for them is markedly curtailed." This was all the more alarming for the United States because "there is one way, a very important way, in which Soviet Russia appears to offer an advantage over us, and that is in the vital matter of racial discrimination ... The fact that Soviet ideology seems to make room for men of all colors and, therefore, nations of all colors, is a most potent political act in the world. Perhaps the most potent of them all." 36 It must be stressed how forcefully Luce related the national and the international levels of the ideological warfare; that is, the potential appeal of communism among African Americans, on the one hand, and, on the other, the fact that "naturally the colored people of Asia, those who are still under white masters, will be inclined, all other forces being equal, to do their ideological shopping in Moscow." Not surprisingly, she emphasized that the issue at stake was mainly ideological: while "military, economic, and political expediency" offered solid arguments in favor of the bill, this was above all a matter of "principle" - the exclusion acts were inspired by "the Hitlerian and Fascist principle ... of racial discrimination" 37 and were, therefore, a violation of fundamental American values.

Again, Luce's quest for an international and multiracial U.S.-led coalition vis-à-vis the coming threat of the cold war was part of a broader pattern. After the war Truman would take the lead in the formation of such a coalition by distancing himself from his Southern Democrat background. It was indeed a slow and partial process, as it had to deal with the reaction of the Dixiecrats in Congress and with the persistence of not exactly 
color-blind orientations in the State Department and in the foreign-policy establishment in general. Furthermore, the American Europe-first strategy of the late 1940s and support for European colonial powers weakened its appeal in Asia and Africa, while persisting segregation and racist violence at home fueled African Americans' activism and was a source of increasing embarrassment abroad. The cold war multiracial consensus taking shape during and in the aftermath of the war was strongly contested, and it is noteworthy that among its early proponents was Clare Luce, who helped to shape it from a conservative-libertarian point of view.

Her Republican allegiance and aversion to Franklin Roosevelt account to some extent for her early advocacy of desegregation in the army. Campaign speeches on the subject, highlighting the failure of the New Deal to address the needs of African Americans and Roosevelt's alliance with Southern Democrats in Congress, had a distinctive partisan tinge and seem to have been mainly driven by party politics. ${ }^{38}$ However, since 1942 Luce was aware that the issue of race relations in America was deeper and had larger implications than just another pretext to embarrass the Democrats. Her article in Opportunity anticipated many of the issues that the shaping of a multiracial anticommunist coalition would face in later years: First and foremost, the contradiction between the emergence of the United States as the global standard-bearer of freedom and democracy and the reality of discrimination and violence that characterized mainly, but not exclusively, the South: "Here at home we are still guilty of practicing some of the hard discriminations and perpetrating some of the same cruel oppressions against our own colored citizens for which we condemn our Axis enemies, and for which, in many cases, we criticize our own Allies in their overseas colonial possessions." That such a contradiction had to be solved was, again, a matter of principle: America was fighting for freedom and stood on the belief that all men are created equal. ${ }^{39}$

Later in the 1940s another powerful pillar joined to sustain the structure of the multiracial, international coalition that Washington had to build in order to gain the higher moral ground vis-à-vis the Soviet Union: religion. Oddly enough, the religious revival of the late 1940s and early 1950s has not yet received the attention it deserves from scholars dealing with the cultural dimension of the cold war. ${ }^{40}$ Indeed, the image of America as the leader of the Christian nations opposed to atheistic communism played a major role in forging an internationalist and officially color-blind cold war consensus at a time when some Americans were accepting with reluctance the postwar United States commitment to world affairs, while others might have considered marxism and Soviet Russia as the only answers to Jim Crow and Strom Thurmond.

The encounter with religion certainly was a major event in Clare Luce's life. In 1946 she embraced Catholicism as the result of a deep personal crisis originated by the sudden death of her daughter, Ann, two years earlier; it is safe to assume that her conversion affected her attitude toward democracy ${ }^{41}$ Her orthodox, mystic faith provided her with both personal 
strength and ideological orientation at a time when the cold war, like World War II a few years before, seemed to justify limitations on liberty and democracy at home in order to attain victory abroad. In a speech before the National Council of Catholic Women in September 1948 she remarked that "if the modern world - our western civilization - can be saved from destroying itself, it is the Catholic woman who must do the major part of the job. But the salvation of our society, the preservation of our democratic way of life, the security of our civilization, are not the goal of the Catholic woman. Her goal, all mankind's proper goal, is the vision of God - not to be attained short of complete submission to His Will. The preservation of western society [. . .] will be the result of perseverance in our goal." While in the early 1940s she had been willing to discard democracy in her quest for "national self-preservation" - and greatness - now she subordinated democracy to what she saw as a higher set of values consistent with Pious XII's cautious acceptance of liberal democracy as instrumental to religious values. ${ }^{42}$

Religion was also the major insipration for a commencement address that she gave at Tuskegee Institute in May 1949. It was, perhaps, the fullest articulation of her views on race relations in America and the cold war: "If you and I had no soul (and if Christianity is a silly myth and there is no God) then I should be a wholehog Capitalist and you should be wholewolf Communists. We should then square off and scrap to the death, with every means and weapon we can lay our hands on to see who can get most of what the other has." 43 Only religion, she preached to the Tuskegee graduates, could avert this ugly scenario of class and racial warfare in America, which sounds reminiscent of her global "Luce Forecast" of early 1942. In her view Christianity was the remedy to what she saw as the crisis of "white man's culture" or, alternately, of "Western civilization": namely, the ascent of materialism in the opposite forms of capitalism, which "ignores man's soul," and communism, which "flatly denies its existence." Unlike the other organized religions, Christianity was able to fulfill both the spiritual and the material needs of the individuals and was therefore the only answer to the moral decline of a highly secularized world that was unable to accomplish the fundamental task of "keeping body and soul together." Luce placed a special emphasis on the material and political implications of the Christian faith by portraying it as the foundation of democracy and social progress. Not only Jefferson's democratic ideal, but also "reforms" inspired by "compassion ... were first introduced in Christian lands, as Christian ideals, in the name of the Crucified God." ${ }^{4}$ By making sweeping references from the Catholic social doctrine to the religious thrust of abolitionism, Luce urged her audience to "decide ... whether you are going to frame your protest in spiritual or material terms, in terms of a real Christian democracy, or the concentration camp ideologies of Harlem or Siberia." 45 But the possibility of a pro-Soviet choice among young blacks was clearly the main concern of Luce, who took time to deride Paul Robeson, "a Communist intermittently bitten with the capitalist spirit," who 
had "greatly hurt his people's cause by giving those prejudiced against the Negroes" a solid argument against them. Thus religion enabled her to accomplish the ultimate U-turn, from white supremacism and fear of "colored" international subversion to the belief that blacks could provide the spark for the moral rebirth of the Western world: "The American Negro could, if he would, play the same role in this dying civilization that the ancient Christians played in Rome." 46 However, extreme as it might seem, her trajectory reflected widespread national and international tendencies to exorcize the specter of racial and class conflict through the appeal of religion.

Her conversion to Catholicism had consequences on her public life as well as her political culture, as in 1953, following the Republicans' return to the White House, it helped her secure the appointment as ambassador to Italy.

She had become involved in postwar Italian politics when she joined her old friend Joseph Kennedy in an effort to gather private, mostly corporate, funds to support the pro-Western Christian Democrats in the crucial general elections of 1948. Such an effort, which generated two milion dollars, had been promoted by a transatlantic Catholic network promoted directly by the Vatican and, in the United States, by Cardinal Spellman of New York.

Her appointment as U.S. ambassador to Italy, which was opposed by Protestant and other groups in the United States, ${ }^{47}$ was largely a reward for the role she and Harry Luce had played in the elections of 1952. A fervent anticommunist, "la signora" - as she came to be called in Rome urged the centrist governments to pursue a more energetic policy against the Italian Communist Party (Partito Comunista Italiano or PCI) and the Communist-led trade unions. While her flamboyant style and amateurish clumsiness raised some eyebrow in diplomatic circles on both sides of the Atlantic, she dutifully applied to Italy the rollback strategy promoted by President Eisenhower and Secretary of State John Foster Dulles. Besides, her direct access to the president and her visibility in the American and Italian media made her an influential figure in Washington as well as in Rome. ${ }^{48}$

However, frustrated by Christian Democrats'(Democrazia Cristiana or DC) reluctance to adopt radical measures against the growing strength and prestige of the PCI, and worried by the instability of Italian governments after the 1953 elections and the death of DC leader Alcide De Gasperi in 1954, Luce soon began to explore alternative paths to the seemingly inevitable U.S. support of the DC, thus departing to some extent from the official U.S. policy toward Italy. In her unofficial diplomatic activity the U.S. ambassador did become well acquainted with reactionary circles of the Roman aristocracy and built close ties with several ultraconservative public figures like Mussolini's former foreign minister, Dino Grandi, the Venetian industrialist, Count Vittorio Cini, and the contro- 
versial Monarchist leader Achille Lauro, thus encouraging the hopes of those Italians who were disappointed by what they saw as the weakness of the DC toward the PCI and the left-wing socialists. Indro Montanelli, a well-known journalist of the leading Italian newspaper Corriere della Sera and a longtime acquaintance of hers, approached her as the spokesman for an informal group of industrialists and bureaucrats - some of them former Fascists - determined to defend Italy at all costs from what they saw as the incumbent threat of Communist subversion, including a rightwing coup. In several letters written to Luce in 1954, Montanelli justified his authoritarian stance by maintaining that in Italian history "majorities have never counted," and that Italy had always been governed by a "minority of a hundred thousand beaters." In America, he added, democracy was deeply rooted in religion, while in Italy it was just a "bureaucratic technique" devoid of any moral basis. ${ }^{49}$ Interestingly enough, his arguments are reminiscent of those utilized by Mussolini with American diplomats $^{50}$ as well as of Anglo-Saxon stereotypes about Italians as an undisciplined and unreliable "Latin race." ${ }^{1}$ Luce took very seriously Montanelli's analysis of Italy as a country lacking democratic traditions and, therefore, needing to be governed by some strong man; indeed, it is safe to assume that her determination to cut U.S. support to the Christian Democrats and direct it to reactionary forces was strenghtened by her familiarity with Montanelli and members of his group. ${ }^{52}$

To be sure, Clare Luce, unlike some of these Italian personalities, was animated by the urge to modernize Italy along pro-free market lines. Christian Democrats' cautious and at times reluctant acceptance of capitalism sounded to her all too similar to the New Deal, and government planning to foster economic growth and reduce social inequalities, like the "piano Vanoni" of 1954, was at odds with the "diffusionist model" implemented by the Eisenhower administration. In the early 1950s, U.S. economic diplomacy, especially toward developing areas like Latin America, emphasized the need for struggling economies to import practices based on American-style free eneterprise as opposed to state action. ${ }^{53}$ Clare Luce shared these views, as well as the virtual equation between democracy and anticommunism that characterized the foreign policy of John Foster Dulles.

While exploring the Italian political landscape in search of a counterpart advocating this agenda, Luce ended up flirting with political and business circles who motivated their support for an authoritarian solution to Italian instability by resorting to the old argument of the congenital inability of the Italian people to live under a democratic government and avoid left-wing subversion. In fact, paternalism and skepticism toward the viability of full self-government in Italy had been part and parcel of American views of Italian politics well into the 20th century. American support for fascism in the 1920s was due, among other things, to the widely shared assumption that, in the words of State Department official Gordon Auchinloss, "Italians are like children. They must be led and assisted more than 
almost any other nation." 54 Even the New York Times columnist Anne O'Hare McCormick, a well-known Italophile, in 1923 described Italians as "a highly civilized but naturally lawless people." 55 And Luce herself referred to Italians' political behavior in paternalistic terms after the 1950s. As late as 1968, while recalling her efforts to curtail the power base of leftwing trade unions in the mid-1950s by excluding from American contracts those Italian companies who did not suspend or fire union activists, she said,

[T] hese people here, what do they care about? Giovanni has to go to the factory, and put spaghetti on the table. That's what his wife is interested in. The day the spaghetti doesn't appear on the table, she says "Whatever you are doing, that is stopping the spaghetti, stop it". And if it's joining a Communist union, she'll say "Get out of the union because the Americans pay for the spaghetti", and that is precisely what happened. ${ }^{56}$

Clare Luce's quest for an authentically conservative, business-oriented, and aggressively anticommunist party as a pressure group on, if not an alternative to, the DC turned out to be highly problematic and, in the end, unsuccessful. The Italian government correctly feared that the U.S. ambassador's attempt at implementing rollback in Italy, let alone her more risky initiatives, would be counterproductive. Her replacement by James Zellerbach at the end of 1956 marked a shift toward a more cautious American approach to Italian politics that was consistent with the general pattern of Eisenhower's foreign policy during his second term. Luce's failed experiment is not extraordiarily relevant to the study of U.S. policies toward Italy. However, it sheds some light on the permanence of remnants of the pre-World War II ideology of American foreign policy in the cold war years.

Anglo-Saxonism as a pillar of the construction of whiteness and a foundation of a hierarchy of race separating superior and lesser stocks of Europeans has particular implications on American views of and attitudes toward Italy. Not surprisingly, it had been among the reasons that account for the American long-lasting support of and widespread sympathy toward Italian fascism from the early 1920 s to the mid-1930s. ${ }^{57}$ Scholars like Michael Hunt and Gerald Horne, among others, have stressed that, though since World War II racialized thinking was excluded from the offical American rethoric, elements of a racialized outlook on world affairs have survived and intertwined with the anti-Communist ideology of the cold war years. In particular, the old assumption that democratic selfgovernment was unlikely to produce its benefits in backward - that is, non-Anglo-Saxon - countries still lingered in the minds of key figures of the American foreign-policy establishment like Dean Acheson and George Kennan. ${ }^{58}$

A few weeks after Pearl Harbor and the American entry in World War 
II, Clare Luce vented a blatantly racist view of what was at stake in war and of the coming role of the United States in world politics. In the following months and years she called for a multiracial national and international coalition vis à vis the Axis powers and, later, international communism; her international outlook and vision of the national interest still influenced her ideas about race and whiteness, although now they led her to totally different conclusions. Finally, a secondary aspect of her diplomatic activity as U.S. ambassador to Italy in the mid-1950s seems to suggest that preexisiting notions about American foreign policy and the "hierarchy of race" survived the decline of the political and cultural conditions that had shaped them.

\section{NOTES}

I thank the Italian Fulbright Commission and the Italian Academy for Advanced Studies at Columbia University for the fellowship support that enabled me to undertake the research for this essay. I am grateful to Greg Robinson for his invaluable suggestions and encouragement and to Tim Borstelmann, Mario Del Pero, and Blanche Wiesen Cook for their comments on earlier drafts. I also want to thank the staff of the Library of Congress Manuscript Division for their assistance.

1. John W. Dower, War Without Mercy: Race and Power in the Pacific War (New York: Pantheon, 1986); Christopher G. Thorne, Allies of a Kind: The United States, Britain, and the War Against Japan, 1941-1945 (London: Hamish Hamilton, 1978); and Akira Iriye, Across the Pacific: An Inner History of American-East Asian Relations (New York: Harcourt, Brace and World, 1967), and American, Chinese, and Japanese Perspectives on Wartime Asia, 1931-1949 (Wilmington, D.C.: SR, 1990).

2. Thomas Borstelmann, The Cold War and the Color Line: American Race Relations in the Global Arena (Cambridge: Harvard University Press, 2001).

3. "Brazil: The Biggest American Republic," Life, November 23, 1936, 43.

4. Ibid., 40-43.

5. For a convincing discussion of the potential and limits of the boom in whiteness studies, see Peter Kolchin, "Whiteness Studies: The New History of Race in America," Journal of American History 89 (June 2002): 154-73.

6. Stephen Shadegg, Clare Boothe Luce (New York: Simon and Schuster, 1970), 113-16; and Sylvia Jukes Morris, Rage for Fame: The Ascent of Clare Boothe Luce (New York: Random House, 1997), 369-88.

7. On the Century Club, see Mark L. Chadwin, The Hawks of World War II (Chapel Hill: North Carolina University Press, 1968), 19, 65-73. See also William vanden Heuvel, "Franklin Delano Roosevelt: A Man of the Century," an address to the monthly meeting of the Century Association, April 4, 2002, available at www.feri.org/news/news_detail.cfm?QID $=954$. The literature on the diplomatic, strategic, and ideological aspects of the Anglo-American "rapprochement" on the eve of World War II is too vast to be summarized here. An interesting and sinthetic analysis is provided by Christopher Thorne in "The Near and the Far: Aspects of Anglo-American Relations, 1919-1945," in Border Crossings: Studies in International History (New York: Basil Blackwell, 1988).

8. Francis Pickens Miller, "The Atlantic Area," Foreign Affairs, July 1941, $727-28$. 
9. Henry Luce, "England Revisited," in David Longwell Papers, box 29, Rare Book and Manuscript Library, Columbia University.

10. Shadegg, Clare Boothe Luce, 82; and W. A. Swanberg, Luce and His Empire (New York: Scribner's, 1969), 182.

11. Michael H. Hunt, Ideology and U.S. Foreign Policy (New Haven: Yale University Press, 1987), 145; John L. Harper, American Visions of Europe: Franklin D. Roosevelt, George F. Kernnan, and Dean G. Acheson (Cambridge: Cambridge University Press, 1996), 69-71; and Chadwin, Hawks of World War II, 19.

12. Joseph Noel Marie Ostyn, Beyond Alliance: U.S. Foreign Policy and the Forging of an Atlantic Community, 1947-1955 (Ph.D. diss., Ohio State University, 1995), 30-43.

13. Clarence Streit, Union Now: A Proposal for a Federal Union of the Democracies of the North Atlantic (New York: Harper, 1939), 90.

14. Union Now speeches, September 11, 1940, and January 22, 1941, in Clare Booth Luce Papers, Library of Congress Manuscript Division (hereafter cited as CBLP), Speech File, box 668 f. 8 and 669 f. 2.

15. T. Christopher Jespersen, American Images of China, 1931-1949 (Stanford: Stanford University Press, 1996), xv-xx.

16. Dower, War Without Mercy, 94-146. On the role of Japan as a racial and geopolitical threat to white supremacy in world affairs, see Gerald Horne, "Race from Power: U.S. Foreign Policy and the General Crisis of 'White Supremacy,'” Diplomatic History 23, no. 3 (1999): 437-61.

17. Joseph M. Henning, Outposts of Civilization. Race, Religion, and the Formative Years of American-Japanese Relations (New York: New York University Press, 2000), ch. 6.

18. Jespersen, American Images, 53-54; and Thorne, Allies of a Kind, 563. Her activity was not limited to public speeches; in a letter to the New York Times columnist Anne O'Hare McCormick, she urged her to pay more attention to Asia as opposed to Europe (Clare Boothe Luce to Anne O'Hare McCormick, May 15, 1946, in Anne O'Hare McCormick Papers, correspondence, box 4, New York Public Library, New York City). The China lobby included, among others, William Bullitt and Representative Walter Judd.

19. Jukes Morris, Rage for Fame, 430-31. On Homer Lea as a geopolitical thinker, see, among others, G. R. Sloan, Geopolitics in U.S. Strategic Policy, 18901987 (Brighton, U.K.: Wheatsheaf, 1988), 93-95.

20. Sloan, Geopolitics in U.S. Strategic Policy, 94

21. Homer Lea, The Valor of Ignorance (New York: Harper, 1909), 45, 58.

22. Ibid., 128, 129, 132. For a broader discussion of American visions of other peoples and anti-immigrant sentiments, see, among others, Matthew Frye Jacobson, Barbarian Virtues: The United States Encounters Foreign Peoples at Home and Abroad, 1876-1917 (New York: Hill and Wang, 2000), chs. 4, 5, and 6.

23. On the widespread interest in and popularization of geopolitics during World War II, see Joanne Sharp, Condensing the Cold War: Reader's Digest and American Identity (Minneapolis: University of Minnesota Press, 2000), chs. 2 and 3; and Susan Schulten, The Geographical Imagination in America, 1880-1950 (Chicago: University of Chicago Press, 2001), ch. 9.

24. Dower, War Without Mercy, 157-58, 336, 344; Jukes Morris, Rage for Fame, 440-41; and Clare Boothe Luce, "Ever Hear of Homer Lea?" Saturday Evening Post, March 7 and 14, 1942.

25. Clare Boothe Luce, "A Luce Forecast for a Luce Century," CBLP, Family and Personal Papers-Luce Family, b. 20, f. 4, 8

26. Borstelmann, Cold War, 30. A useful "state of the art" essay on the often vague idea of "the establishment" is that by Priscilla Roberts, "All the Right People': The Historiography of the American Foreign Policy Establishment," Journal of American Studies 26, no. 3 (1992): 409-34. 
27. Luce, "Luce Forecast," 3. On Anglo-Saxonism in the U.S. Foreign Service, see Robert Schulzinger, The Making of the Diplomatic Mind: The Training, Outlook, and Style of United States Foreign Service officers, 1908-1931 (Middletown, Conn.: Wesleyan University Press, 1975), chs. 1 and 6; and Martin Weil, A Pretty Good Club: The Founding Fathers of U.S. Foreign Service (New York: W. W. Norton, 1978).

28. Luce, "Luce Forecast," 9-10, 11.

29. See Hunt (Ideology, 152) on geopolitics as a "new formulation undergirding the old ideology [of U.S. foreign policy] during and after World War II."

30. Luce, "Luce Forecast," 19, 23, 24-25.

31. Ibid., 24, 26.

32. Ibid., 9, 22-23, 31 .

33. "A Plea for Racial Unity," Opportunity 20, December 12, 1942, 355.

34. Quoted in Borstelmann, Cold War, 60.

35. Speech at the Institute of Art and Sciences, Columbia University, July 6, 1943, quoted in Shadegg, Clare Boothe Luce, 178.

36. Speech at the House of Representatives, October 8, 1945, CBLP, Speech File, box 678, p. 5 .

37. Ibid., 13.

38. "The Negro True Friend: The Republican Party," 1942, and "The New Deal Skin Game," 1944, CBLP, Speech File, box 677.

39. "Plea for Racial Unity," 355-56.

40. For a useful overview, see Leo Ribuffo, "Religion and American Policy: The Story of a Complex Relationship," National Interest 52 (Summer 1998): 36-51.

41. See her account of her conversion to Catholicism in "The 'Real Reason', McCall's, February, March, April 1947. On the conversion to Catholicism in 20thcentury United States and Britain, see Patrick Allitt, Catholic Coverts: British and American Intellectuals Turn to Rome (Ithaca: Cornell University Press, 1997).

42. "The Catholic Woman in the Modern World," CBLP, Speech Files, box 682, folder 15, Library of Congress, Washington, D.C.

43. "Saving the White Man's Soul," CBLP, Speech File, box 683, p. 33

44. Ibid., 21.

45. Ibid., 36 .

46. Ibid., 42 .

47. Maree-Anne Reid, “Kiss the Boys Goodbye': Clare Boothe's Luce Appointment as United States Ambassador to Italy," Australasian Journal of American Studies 16, no. 2 (1997): 45-67.

48. The best account of Clare Luce's activity as ambassador to Italy is that by Mario Del Pero, L'Alleato scomodo: Gli USA e la DC negli anni del centrismo (1948-1955) [The Inconvenient Ally: The United States and the Christian Democrats in the Years of Centrism (1948-1955)] (Rome: Carocci, 2001). See also Del Pero, "American Pressures and Their Containment in Italy During the Ambassadorship of Clare Boothe Luce, 1953-1956," Diplomatic History 28 (June 2004): 407-39.

49. Del Pero, “Anticomunismo d'assalto: Lettere di Indro Montanelli all'ambasciatrice in Italia Clare Boothe Luce" [Storming Anti-Communism: Letters of Indro Montanelli to American Ambassador in Italy Clare Boothe Luce], Italia Contemporanea 212 (September 1998): 633-46. Several letters from Clare Luce to Indro Montanelli confirm that the ambassador counted on Montanelli as one of her confidential sources about Italian politics, especially during her first year in Rome (see Indro Montanelli Papers, Maria Corti Manuscript library, University of Pavia).

50. Quoted in David Schmitz, Thank God They're on Our Side: The United States and Right-wing Dictatorships, 1921-1965 (Chapel Hill: University of North Carolina Press, 1999), 41 
51. Matthew Frye Jacobson, Whiteness of a Different Color: European Immigrants and the Alchemy of Race (Cambridge: Harvard University Press, 1998), 5662.

52. Del Pero, "Anticomunismo d'assalto."

53. Mark T. Gilderhus, "An Emerging Synthesis? U.S.-Latin American Relations Since the Second World War," in America in the World: The Historiography of American Foreign Relations Since 1941, ed. Michael J. Hogan (Cambridge: Cambridge University Press, 1995), 438-39.

54. Quoted in Schmitz, Thank God, 30.

55. Marco Mariano, "Gender and International History: Public and Private in Anne O'Hare McCormick's Journalism (1921-1954)," in Public and Private in American History: State, Family, Subjectivity in the Twentieth Century, ed. Raffaella Baritono, Daria Frezza, Alessandra Lorini, Maurizio Vaudagna, and Elisabetta Vezzosi (Turin: Otto, 2003).

56. Interview with Clare Boothe Luce by John Luter, January 11, 1968, transcript, 46-50, Columbia Oral History Project, Rare Book and Manuscript Library, Butler Library, Columbia University, New York City. In fact, the impact of U.S.sponsored anticommunist measures in Italy was quite limited.

57. John P. Diggins, Mussolini and Fascism: The View from America (Princeton: Princeton University Press, 1972), ch. 1; and Schmitz, Thank God, chs. 1 and 3 .

58. Hunt, Ideology; Horne, "Race from Power"; and Anders Stephanson, Kennan and the Art of Foreign Policy (Cambridge: Harvard University Press, 1989), esp. $157-75$. 